\title{
Statehood, Power, and the New Face of Consent
}

\author{
SHELDON LEADER ${ }^{\star}$
}

\begin{abstract}
Individuals and groups are often subjected to power, both public and private, by eliciting their consent. Debate usually focuses on whether or not that consent is freely given or is vitiated by imbalances of strength between the bargaining parties. This essay focuses on a different issue, one that is largely passed over in legal and moral analyses: how far does and should consent bind one to accepting in advance changes in the future? There are signs of a fundamental shift in answering this question-a shift that particularly concerns the control of power in the economy. Industrial democracies may be abandoning a conception of consent rooted in the model of the social contract. They may be moving toward a conception that requires the consenting parties to take on risks about the future that are more thoroughgoing and potentially damaging than would be allowed under the earlier model. Examples of this phenomenon will be drawn primarily from two domains in which issues of consent to economic power are central: employment law and international investment law. The evolution of legal principles of consent at work here will be critically evaluated with the help of the tools of political theory. It is an analysis that deliberately selects examples in order to illustrate positions rather than to provide an exhaustive account of the prevalence in different countries and sectors of the problems highlighted. That is a task for follow-up empirical investigation.
\end{abstract}

\section{INTRODUCTION}

The dimensions of "statehood" are shifting, along with those of the state itself. The latter refers to an institution, the former to the rationale and legitimacy of that institution. The former will, of course, affect the course of the latter: its vision of statehood, explicit or implicit,

^ Professor, University of Essex School of Law; Director, Essex Business and Human Rights Project.

Indiana Journal of Global Legal Studies Vol. 23 \#1 (Winter 2016)

(C) Indiana University Maurer School of Law 
guides the state as it widens or shrinks the scope of its own powers and varies the division of labor between itself and bodies lying outside of it.

Changes in conceptions of the mission of the state have sometimes led beyond drawing a stark contrast between the principles regulating public and private power and toward a synthesis of principles governing the exercise of power per se-be it located within the state or outside of it-in civil society. One vantage point from which we can watch this convergence of public and private standards is through a fundamental value on which the legitimate exercise of power is often grounded: consent. My focus here is on the way consent is able to reach into the future so as to anticipate changes. Change may be the concern of an enterprise as it reworks its structure and strategy and presents employees with the demand that they follow along, on the grounds that the employees consented in advance to a given alteration. It may also be a concern of the state itself as it alters its public policy objectives and tries to refute claims that the state consented in advance to an agreement with an investing business that the state would not impose the cost of such policy changes on that business.

In both of these cases, as well as others to be mentioned, there is a shift in the way these undertakings about the future are regulated.

\section{CONSENTS AND FUTURES: SOME EXAMPLES}

\section{Consent to Change in Employment Conditions}

A rich source of principles governing consent to change can be found in the workplace. Employment law, until recently, has offered what can be called the classical model of protection of the vulnerable from the impact of radical change. ${ }^{1}$ It also reveals shifts away from that model. In the approach to employment rights that has held in many industrial democracies through much of the twentieth century, the state has enforced a floor of protected entitlements for the employee. Some of these guarantees operate via statute, such as minimum wage or nondiscrimination requirements, while other guarantees arise via law developed in the courts. The latter contribute to setting up the initial expectations of the employee and employer about, for example, the wage over and above the statutory minimum and the content of the job to be done, as well as other core conditions that mark the reasons for which the contract was entered into by the employee and employer in the first place. At the same time, the parties project their relationship into the future. Here the law has traditionally allowed the employer to impose a

1 Here I focus on U.K. employment law for the purpose of illustrating the phenomenon. 
certain degree of change unilaterally, that is, without needing to obtain fresh consent from the employee because acceptance was implied in the initial undertaking. This embraced reasonable changes in conditions of work arising from shifts in the enterprise's structure or strategy. ${ }^{2}$

It is here that the problem of the reach of consent arises. Everything turns on the scope of the employer's prerogative unilaterally to impose changes to the terms and conditions of employment initially agreed. In the classical picture, the agreement given in the initial contract commits the worker to accept some changes to the terms of the working relationship but not changes that are so severe that, had he been faced with these conditions at the outset, he would never have taken the job. ${ }^{3}$ It is, for example, one thing for a school teacher to agree in advance that she will need to adapt to new computer technology as an aid to doing her job but quite another to be required to accept a new computer program which largely obviates the need for her to exercise judgment in interpreting material and evaluating student responses.

On the classical approach, she cannot be taken to have consented in advance to the latter outcome: a change that works so much to her disadvantage that, had she been presented with this condition of work at the outset, she would not have wanted the job. This does not mean that such a change cannot be proposed by the employer, and formally accepted by the employee. But if it is, this would be a fundamental alteration of the existing contract, and the employee's fresh consent would be necessary. ${ }^{4}$

This protective principle is weakening. That is, agreements that bind employees may commit them in advance to accept changes that leave them in a substantially worse position than they were when they initially agreed to their terms of employment. ${ }^{5}$ This result stems from the fact that individual consent in the workplace is changing in its force and meaning. It has begun to break free of its classical limits and is being replaced by a conception according to which the consenting

2 See SimON DEAKIN \& GILLIAN S. MORRIS, LABOUR LAW 295 (6th ed. 2012).

3 See id. (stating that the employee's implied duty not to obstruct new technology or new forms of work organization does not extend to overriding the employee's core expectations regarding pay, hours of work, or employee benefits on which there was initial agreement with the employer).

4 If the employee does not give consent, the dismissal is not automatically illegal. If the employee rejects the change, she is then entitled to make the employer justify the firing, which it may or may not succeed in doing, under the special reasons specified by laws governing the fairness of dismissal. See HUGH Collins ET AL., Labour LAW 162-177 (2012).

5 See, for example, the principles formulated in the U.K. cases of Cresswell v. Board of Inland Revenue [1984] Ch.D. 508 at 509; and Carlton Henry v. London General Transp. Services [2002] EWCA (Civ) 488, [26]. 
individual embraces a radically larger field of risk-a gamble in which he hopes he will continue to gain from future changes but accepts in advance that he may end up much worse off. This is what we find in "flexibility" clauses in employment contracts that obligate the employee to accept any task the employer sets. ${ }^{6}$

To anticipate the discussion to come, the classical conception of consent implies the acceptance of what can be called restricted risk about the future, opening the employee to a limited set of possible changes he is deemed to have accepted beforehand. This is being replaced by a conception of consent as a commitment in advance to a much wider set of possible changes. I call this the assumption of extended risk about the future. In what follows, these two species will be referred to as restricted and extended consent, respectively.

\section{Consent to Change in International Economic Law}

The emergence of extended consent is a phenomenon that is not limited, of course, to employment relations but reaches into many other domains in which the regulation of power and the management of change are brought together. My second example concerns the state itself as one of the parties to an agreement with a private party. A salient illustration is that of contracts for investment. In these contracts, private companies undertake major projects for host countries, and the latter in turn give undertakings that the companies seek, aimed at making their investments secure and profitable. In pursuing this objective, international economic law displays a movement away from the principle that the state cannot tie its hands by certain contractual promises to those under its power. This principle is usually reflected in the classical notion in domestic legal systems that the state cannot agree to be bound not to change a policy that is central to its responsibility to further the public interest-a duty that may call for shifting priorities over time, including those concerning fundamental rights that need protecting. ${ }^{7}$ Protecting a right might, on the classical

6 Consider the following clause from a specimen contract: "[t]he Company reserves the right to vary these terms and conditions for operational, commercial or financial reasons according to the needs of the business." COLLINS ET AL., supra note 3, at 109. Such a clause "provides the employer with an apparent power to vary any term of the contract unilaterally for business reasons." Id. at 172.

7 See Peter Cane, An Introduction to Administrative Law 145 (3d ed. 1996). The state retains the equivalent freedom to alter its commitments for what are called special administrative contracts granting a concession, which is a species of contract that would be vulnerable to alteration in the public interest. For an analysis of the line between consents by the state that are and are not legitimately binding, see Susan Rose-Ackerman \& Jim Rossi, Disentangling Deregulatory Takings, 86 VA. L. REV. 1435, n.110 (2000). See 
view, have to take priority over the enforcement of a contract if the latter unduly limits the former. Contracts with private parties cannot be allowed to shrink the state's policy space-a space that must leave room for government to change course at its discretion in order to respond to these fluid needs. ${ }^{8}$

Investors often see this as a problem-a gap that needs filling. In the name of stabilizing investment expectations, investment contracts often contain promises by the state not to apply changed law to an investment, with significant damages for breach. International arbitral tribunals are usually given the mission of interpreting and giving effect to these contracts, and they largely uphold this approach. ${ }^{9}$ These decisions insist that the state can be bound by its consent to precisely the undertakings that classical domestic public law forbids. ${ }^{10}$ This is accomplished by crossing two streams of legal principle: that which governs state contracts under domestic and private international law on the one hand and that which governs treaties under public international law on the other. In order to take advantage of the analogy with treaties, the contract is "internationalized," a label that allows the tribunal to appeal to the principle, central to the law of treaties, of pacta sunt servanda. ${ }^{11}$ This is accompanied by borrowing the principle of international law that the state, in making a treaty, will not normally be allowed to appeal to any domestic constitutional limitations on its capacity to make binding promises in such an agreement. ${ }^{12}$

Public and private international law here can combine forces to strengthen the grip of private economic actors over the state. For example, over the lifetime of an investment project, such as the development of an ore deposit, a state that is relatively poor may find that it is bound by a human rights treaty to improve legal standards protecting the health and safety of workers but may face the obstacle of having given its prior promise not to change the law applied to the investor's project. Rather than pay damages for breach of contract-the state itself compensating the business for the higher cost of worker

also M. Sornarajah, The International LaW on Foreign InVEstment 293 (3d ed. 2010).

8 SORNARAJAH, supra note 7.

9 A classic example is the arbitral decision in Texaco v. Libyan Arab Republic, 53 I.L.R. 389 (1977).

10 For contrast, see SORNARAJAH, supra note 7.

11 That is, "agreements must be kept," a principle of international law discussed in SORNARAJAH, supra note 7, at 244, 296

12 See Vienna Convention on the Law of Treaties art. 27, 27 Jan. 1980, 1155 U.N.T.S. 331

("A party may not invoke the provisions of its internal law as justification for its failure to perform a treaty.”). 
safety-the state may prefer to withhold the higher level of health and safety protection from the project. ${ }^{13}$

As different as this example may seems from employment, the two share the transition from a restricted to an extended assumption of risk via the instrument of consent. Try as it might, the state cannot tie itself via contract to a fixed set of policy goals under national law. Government has a notionally fiduciary role in relation to its subjects, which contracts cannot be allowed to prejudice. But as government moves into the arena of international investment agreements, things change: it can find itself tied to a far more thorough undertaking that could lead it, for fear of paying substantial damages, to act against the public interest that government is meant to further.

\section{Consent as Renunciation of Basic Rights}

A final set of examples illustrates a different but allied problem. We find situations in which private parties consent to renounce-to alienate-a basic right. This might happen, for example, when employees are permitted to agree to give up their rights not to be unfairly dismissed in exchange for shares in the company ${ }^{14}$ or to give up their trade union rights in exchange for cash. ${ }^{15}$ These situations again raise questions about the appropriate reach of consent. Can agreements legitimately extend so far as to remove the very presence of a basic right, or does it properly come up against a limit: a set of basic, inalienable rights? The new face of consent is open to invitations to renounce these rights, an invitation that consent based on restricted risk would refuse.

To return to the example of investment agreements, states too may consent to renounce such rights on behalf of their citizens, as when they agree with companies that the latter can establish themselves in certain zones in which a much weakened version of trade union rights is on offer or in which other employment rights will not apply at all. ${ }^{16} \mathrm{In}$

13 See Amnesty International U.K., Human Rights on the Line: The BaKU-TibilisiCEYHAN PIPELINE PROJECT passim (2003).

14 See Growth and Infrastructure Act, 2013, c. 27 § 31(1) (U.K.).

15 These agreements were attempted by a past U.K. government but found by the European Court of Human Rights to be in violation of the European Convention. See Wilson, Nat'l Union of Journalists \& Others v. United Kingdom, 2002-V Eur. Ct. H.R. 49; Sheldon Leader, Human Rights, Power, and the Protection of Free Choice, in STRATEGIC Visions FOR HuMAN RIGHTS: EsSAYs IN HONOUR OF KEVIN BOYLE 81-90 (Geoff Gilbert et al. eds., 2011) [hereinafter Human Rights].

16 See, e.g., InT'L TRADE Union CONFEDERATION, Internationally RECOGNISED CoRE LABOUR STANDARDS IN NigERIA 2-4 (2011) (pointing to instances in which Nigerian 
doing this the state might purport to be acting with the democratic consent of its citizens but in a "compartmentalized" fashion: ${ }^{17}$ that is, some of those deemed to be within the democratic consensus, and working in zones without trade union rights or a minimum wage, are taken to have agreed to the possibility of finding themselves in dire need of precisely those rights that the state has, on their behalf, foregone.

In all of these situations, both public and private, the logic and force of consent is shifting.

\section{THE SOCIAL CONTRACT AS BENCHMARK}

The concrete examples I have given all involve matching a situation prior to an agreement with one that comes after it. But, with respect to changes in an organization's future, what force is there in asking about the past, about whether the losses that an individual or group might have agreed to shoulder are fair by comparison with their situations before the agreement was made? Theories of the social contract give us the most thorough attempt to answer this question. While they vary among themselves, the contractarian theories that most closely map the contours of my topic all invoke a precontractual situation. ${ }^{18}$ This is expressed as Locke's "state of nature" 19 or, more recently, as Rawls's "original position." 20 Though differing from one another, these theories have in common a comparison of situations prior to agreement on the fundamental principles governing society with the actual principles that operate once the agreement has been made. The latter are justified to the extent that they match the former. We can use the logic of these theories as a benchmark against which to measure the modern face of consent. When we do this, special features of that modern face emerge.

workers are deprived of benefits of unionization due to government relations with private enterprises).

17 This point was suggested to me by Daniel Augenstein.

18 It is a model that has flaws, not least to do with its vulnerability to the ideological manipulation of what counts as "natural" within the set of elements that one notionally quits the state of nature in order to preserve. Does private property belong there? Does the interest in freedom from association alongside the freedom to associate belong there? These clear reasons for being skeptical of some attempts to read off a set of natural rights from the qualities of a state of nature should not weaken its attraction for our present purposes. For consideration of Marx's critique of consent, arguing that he did not wholly reject its relevance, see Sheldon Leader, Inflating Consent, Inflating Function, and Inserting Human Rights, in CAPITALISM AND HuMAN RIGHTS 28-47 (J. Dine and A. Fagan eds., 2005).

19 See John Locke, Second Treatise on Civil Government, chs. II, IX § 131 (Laslett ed. 1960).

20 See John RaWls, A Theory of Justice 11 (1971). 


\section{A. Consent as Assumption of Two Types of Risk}

In the employment example, and in the example of state promises to investors, we have seen that the parties look into the future and take a risk that the relationship with one another will not work out as each hoped it would. As indicated earlier, there are two ways of understanding that reach into the future: as the assumption of restricted risk and of extended risk. The restricted-risk conception draws a baseline. This line fixes the basic interests to be protected in order for it to make sense for someone to leave the precontractual order and submit to the contractual order. For any given individual, if those basic interests are not protected, then his consent has reached its limit, since, as Locke puts it, "no rational creature can be supposed to change his condition with an intention to be worse." ${ }^{21}$ Above that line, one takes the risk of not being in as good a position as he had hoped to be, but he is still legitimately required to submit to that order. The employee, in my example, would have to accept changes he may prefer to avoid, so long as they do not undermine the whole reason for his being in this particular employment. ${ }^{22} \mathrm{He}$ does not consent to being pushed below that baseline. Change to which the employee can be taken to have given his consent is always, on this approach, shadowed by change to which he did not consent.

It is tempting to criticize this restricted-risk conception of consent as a charter for unworkable fragmentation: different people within a group consenting to an arrangement might enter into the same agreement with different initial expectations. The restricted-risk conception requires comparison of any given change with the initial expectations about the future, distributed among the individuals entering a contract with the same organization, and does so in order to have a benchmark for deciding how radical a subsequent change proposed by that organization is. If so, then these expectations among the entrants are many and various, opening the way to a cumbersome need to assess

21 "But though Men, when they enter into Society, give up the Equality, Liberty, and Executive Power they had in the State of Nature, into the hands of the Society, to be so far disposed of by the Legislative, as the good of the Society shall require; yet it being only with an intention in every one the better to preserve himself his Liberty and Property; ([f]or no rational Creature can be supposed to change his condition with an intention to be worse) the power of the Society, or Legislative constituted by them, can never be suppos'd to extend farther than the common good ...." See LockE, supra note 13, § 131 (emphasis in original).

22 The state in our example would have to accept that its citizens might not benefit from some of its social regulations that apply elsewhere in society because of the stabilization clause signed-but which are not such an extreme reduction of that protection that the state's legitimate authority over those who lose out has vanished. 
situations case-by-case in order to see if the contract has been broken. However, this was not what Locke had in mind, nor could any workable principle of consent to the exercise of power.[TK1] When Locke says that "no rational creature can be supposed to intend to be worse-off" as a result of leaving the state of nature, he is not saying that the postcontractual situation is in all respects better than the precontractual one for any given individual. It is only in some respects that this is so, namely with respect to the core interests in the preservation of liberty and property that are better provided for by legitimate government. These constitute the reasons for consenting to leave the state of nature, and if the terms are not satisfied, the consent has reached its limit. This is a baseline. There are many other things that any given individual might also want and entertain as a precontractual expectation-such as the prospect of becoming a large land owner-and which might be added to this individual's set of basic reasons he had for giving his consent. But these reasons do not, for Locke, count. That degree of deference to each individual's particular expectations would indeed fragment the polity. Only the fundamentally important interests that all share are distilled in the representative individual whom Locke calls a "rational creature," which sets the reason for and limits to consent.

The present argument aims to transpose Locke's logic to the wider settings in our previous examples. Consider the earlier case of a teacher who agrees to accept future "changes in her mode of work" without any further specification of what this phrase means in her contract. The employer might claim that by this undertaking she had in advance agreed to, for example, computers taking over all exercise of judgment in teaching and evaluating students, reducing her to the manager of a machine. On a restricted-risk conception of consent this would not be acceptable. To allow her initial consent to have this grip on her future would arguably force her to accept a transformation of the profession into one that she and others like her would never have wanted to enter had they been asked at the outset. ${ }^{23}$

The rival, extended conception of consent, by way of contrast, does signal willingness to run the risk of being pushed below that baseline. It thereby introduces a radically different way in which consent manages the relationship between individuals, the organizations affecting them, and their futures. It is a conception that cuts its moorings to the core principles underlying the social contract, substituting for them a quite distinct approach. By accepting radical loss as well as radical benefit as

23 This would, in turn, be different from a demand by a particular teacher that she remain working with students of a particular age group when no specific undertaking about this had been made. 
possible outcomes, there is no longer a need to compare, for each and every concerned individual, his position before and after the entry into the consensual arrangement. Instead, by accepting the extended set of outcomes each individual faces a shrunken entitlement to peer back into the past so as to see how far his legitimate expectations have or have not been met. His room for legitimate dissent-grounded on the frustration of those expectations-is reduced.

Having lost this anchor to the particular expectations of the contracting individuals, consent becomes an instrument by which those individuals are tied more closely to the full range of outcomes that their relationship generates in the future. Consent becomes more of a linking device, binding people to institutions, and less of a protective device, preserving people from abuse by those institutions. As such, consent becomes an effective tool of policy. Organizations, both public and private, can work toward results that benefit some while leaving others less well off than they were when contemplating membership, while the latter are not in a position to claim that the agreements affecting their futures have been violated. All are carried along by the same initial and far-reaching undertaking to accept a wide range of outcomes. ${ }^{24}$ This approach can dramatically weaken the force of individuals' control over their material lives. It moves them away from a stable environment and closer to the instability exemplified by the casualized laborer.

\section{B. Consent as Renunciation of Basic Rights}

The choice between the restricted and extended species of consent can carry yet more radical consequences. The latter allows basic rights to be renounced while the former draws a boundary, marking these rights as inalienable. In political economy, the possibility of such renunciation is the fruit of a conception of statehood that lessens the burden of basic rights on "dynamic" enterprise by inserting the consenting individual, and, with due adjustments, the consenting state, between those rights and limits on their exercise. This development provokes an old and fundamental question: why does, and why should, someone agree to give up - to alienate-a right in this way?

So long as there is no coercion or fraud, there are two likely reasons. The first is that the right has little value to the persons giving it up because they do not expect to avail themselves of it. The second is that, even though the right does mean a great deal to them, something they

24 Sheldon Leader, Inflating Consent, Inflating Function, and Inserting Human Rights, in CAPITAlisM AND HumAn Rights 28-47 (Janet Dine \& Andrew Fagan eds., 2005). 
want even more will not be available if the right is retained. In the context of employment, for example, an employer might be willing to provide work only on condition that the applicant agree to forego his rights against unfair dismissal. Similarly, in the context of state investment contracts, investors might demand that if they are to engage the project the state must renounce certain key employee or land rights of local populations. ${ }^{25}$ The call to contract away the right is often informally buttressed with the observation that "half a loaf of bread is better than none."

The extended conception of consent accepts this logic. A restricted conception, following the logic of a social contract, rejects it. Putting the two alongside one another helps to track this important change in the state's view of its proper role. For the extended conception, if I agree that I renounce my right, say, to join a union, this is properly grounded in my estimate that I will not need the union in the future. There is no difference, from this perspective, between deciding not to join a union because I simply do not want to and my agreeing to give up my basic right to do so. The latter is simply a projection into the future of my estimate of where my preferences will lie, and, in agreeing not to join, I take the gamble that my preferences on this point will not change. If they do change, so much the worse for me. On the restricted conception, there is a fundamental difference between deciding to do or not to do what you have a clear right to do, and going further to give up the right to choose to do or not to do that thing. ${ }^{26}$ The latter lies within a realm that-on the restricted conception of consent-one's agreement cannot remo[TK2] $v e$.

Why not? Here we need to amend the answers given by the classical social contractarians to fit modern conditions while staying within the spirit of their argument. ${ }^{27}$ Take the example of agreeing to forego the right to join a trade union. It is one thing for me to decide not to join a

25 See, e.g, AMNESTY INTERNATIONAL, supra note 13.

26 See generally Terrance McConnell, The Nature and Basis of Inalienable Rights, 3 LAW \& Phil. 25, 47-48 (1984) (citing Thomas HobBEs, LEVIATHAN: PARTS I AND II 112 (Herbert W. Schneider ed., 1958)) ("There are some rights, Hobbes says, which are such that a person could never benefit by transferring or relinquishing them. The right . . . to resist assault is, Hobbes claims, such a right. . . . What a person cannot give up is the right to choose whether to resist an assault.").

27 See McConnell, supra note 19, at 44-52 (explaining the views of Locke, Hobbes, and Rousseau). See generally Sheldon Leader, Freedom and Futures: Personal Priorities, Institutional Demands and Freedom of Religion, 70 MoD. L. REV. 713, 713-30 (2007) [hereinafter Freedom and Futures] (introducing two hypothetical situations to illustrate fundamental issues of ethics and law concerning choice); Human Rights, supra note 11, at 82-84 (arguing that "the law of human rights which deals with the basic liberties is not best understood, in its most fundamental form, as a way of controlling imbalances of power."). 
particular trade union, and quite another for me to agree to give up the right to choose whether or not to join the union at all. Renouncing the latter fails to recognize that many basic rights are devices attuned to the right holder's changing priorities. ${ }^{28}$ The basic right to join a union is as available to the sworn enemy of such organizations as it is to their staunch advocate. Equally, the right to manifest one's religious belief is as available to an atheist as it is to the devout. It is there for the former in the event that she changes her convictions, sometimes without choosing to ${ }^{29}$ and hence her priorities. The message behind this feature of the right is that no one can know the future on this point, and one therefore cannot be bound in advance to ignore a priority in life that one cannot foresee having.

To declare someone unable to alienate a right is not to treat her paternalistically. Inalienability is not imposed because someone else knows her future better than she does. It is rather that the shape of the future along these axes cannot be known by anyone. This is precisely what a conception of consent as the extended assumption of risk refuses to acknowledge. It holds the individual to the priorities expressed at the outset, with no room for revision later. It is such revision that the partial risk conception of consent, by contrast, permits.

To alienate a basic right might also undermine its significance in the social order. For example, if an employer can buy an employee's entitlement to accept or refuse trade union membership, then the whole reason for having this right in civil society is undermined. The right is designed to be exercised based on the qualities of the union offering itself as a representative of employee interests. The individual concerned should therefore decide for or against union membership on its own merits, not on the basis of its merits as mixed with the collateral attractions of accepting a reward. The right to join a union is like the right to vote. The latter is designed to reflect the voter's evaluation of candidates on their own merits; a reward for voting a particular way, or not voting at all, is objectionable because of the extraneous motives it introduces. The extended conception of consent invites the influence of these extraneous motives; the restricted conception protects against such influence.

28 See Freedom and Futures, supra note 27, at 718-19 ("Through time . . . this pattern of priorities may change: a new value may displace another as the most important. The person who quietly congratulates or condemns herself may do so for reasons that she would have scarcely recognized some years previously.").

29 See id. at 720. 


\section{C. "Half a Loaf Is Better Than None"}

The most prevalent form of alienation of basic rights involves an invitation to sacrifice one basic right in order to enjoy another. This is often accompanied by the warning that if the former is not given up, then the latter will not be available. As seen in the earlier examples, there are many such situations. An impoverished state may be told by a potential investor that a project will only be undertaken if health and safety laws, or laws protecting local farmers from expropriation, are held static while the protections in the rest of the country continue to increase. An employer might, to elaborate on the earlier example, demand that an employee accept a weaker set of job protection rights, otherwise there will be no job at all. Such proffered trade-offs extend, of course, beyond the pressures exerted in the world economy. It is also what is on offer, for example, when citizens are asked by the state to choose between the preservation of their right to privacy and their protection from clandestine terrorists.

In each of these situations the state often insists that it is satisfying rather than foregoing respect for a human right and that it is doing so with the consent of those involved. In fact, this position abandons a key feature of consent as it figures in the logic of a social contract. A state of nature is a set of disadvantages from which one wants to move away; it is not a single disadvantage. On Locke's approach, for example, one has a reason for leaving the state of nature in order to secure the protection of physical possessions but also to gain freedom from arbitrary power such as can be provided by an impartial judiciary. If one were to have proposed to Locke as a reason for leaving the state of nature the protection of property alone-at expense of putting up with arbitrary dictatorial government-he would likely have deemed her to have lost the plot. She would have failed to appreciate that the vulnerabilities Locke described were all of a piece and cannot be disaggregated. The concern is to protect a range of rights, which the protection of a single right could not deliver.

To preserve the whole set of rights, and to refuse that one be sacrificed to another, is not an invitation to impasse. Here there is an important distinction between a legitimate compromise between one basic right and another, when it is not possible to maximally satisfy either, and a long-range sacrifice of one basic right to another. A strategy of compromise between competing rights will give priority to one over the other but under the condition that the incursion be a fair balance-not a sacrifice of one to the other. To compromise between competing rights means ensuring that in any given case one has found 
the solution that gives adequate space for each. If this does not happen-if one right takes automatic priority because the other has been renounced at the outset-then the right that survives becomes a vortex, absorbing and relegating to second place all other potentially rival interests in all circumstances.

To see what is lost by this strategy, consider the competition between the well-recognized right to life and the equally well-recognized right to freedom of movement. ${ }^{30}$ Preservation of life is ultimately more important than is the interest in freedom of movement, say, along the highway. But it is not true that each and every death risk level is more important than is any given level of freedom of movement. ${ }^{31}$ Assume that evidence shows that the death rate on a highway is reduced by a significant but decreasing number for every mile per hour of reduction in permitted speed. Assume that the reduction is 10,000 deaths per year in a given population for every mile per hour of reduction between 100 and $90 \mathrm{mph} ; 1,000$ deaths from 50 to $40 \mathrm{mph} ; 100$ from 40 to $20 \mathrm{mph} ; 10$ from 20 to $10 \mathrm{mph}$. At a certain point a polity may, and sometimes must, reverse the direction of compromise. In this example, it must at a certain point limit the attention paid to the risk of death in favor of the right to freedom of movement, however clearly a certain number of deaths are linked to a further reduction in speed. Freedom of movement is usually prized less than is the right to life, but it does normally carry some weight in most polities, and to the degree that it does it enters into this minimal competition with the need to prevent deaths on the highway. Even though the preservation of life is ultimately more important than is freedom of movement, it does not follow that the right to freedom of movement must always be adjusted downward so as to have the least impact on the death rate. Yet, such would be the case if the right to freedom of movement was removed at the outset as a basic entitlement in order to allow maximum room for the right to life to flourish.

It follows from this argument that the pursuit of one basic right should not systematically prevail over another right whenever the two compete. To give one right such automatic preference can deprive the polity of one of the tools for spreading responses over the range of

30 An example drawn from Jeremy Waldron, Rights in Conflict, 99 ETHICs 503 (1989).

31 Cf. Waldron, supra note 30, at 509-12, 516-18 (1989) ("For example, if an individual's interest in speaking freely is important enough to justify holding the government to be under a duty not to impose a regime of political censorship, it is likely also to be sufficiently important to generate other duties . . . ."). See also Sheldon Leader, Collateralism, in 4 GLOBAL GOVERNANCE AND THE QUEST FOR JUSTICE: HuMAN RIGHTS 53, 60-61 (Roger Brownsword, ed., 2004) (“[W]hen basic rights compete with one another, civic principles require that the exercise of one such right is not always to be compromised in favour of another."). 
situations that may arise in the future. If a state gives up one basic right of its citizens to allow them to enjoy the goods protected by another right, that state is prevented from dealing with those situations in which common sense and sound ethics would call for a change in priorities. It may be that there are certain situations in which, for example, the enjoyment of the right to privacy has to be compromised in favor of enjoyment of the right to life. But, as with the example of the highway, there are points at which any marginal gain in protection of life is not worth the degree of loss of the right to privacy. Judging when that point is reached is, of course, difficult. But it is nothing compared with the difficulty faced by a society without an effective right to privacy, or a right to a fair trial, so that the right to life can gain an extra margin of protection.

\section{CONCLUSION}

This is a plea for a reinstatement of a conception of statehood that is faithful to the inspiration of theories of the social contract. Stripped of its ideological clothing, whereby what is deemed "natural" is in fact a label behind which are concealed contingent special interests, ${ }^{32}$ it is a logic that is relevant to some of the most important contemporary concerns about the abuse of public and private power. In this area, public and private options begin to converge, and solutions that are faithful to human rights are increasingly available to both domains on the same terms. This plea for a restricted conception of consent is as applicable in the private domain as it is in the public.

Furthermore, the plea for a restricted conception has nothing to do with the balance of power between the weak and the strong. The warnings against a use of consent to lead people to gamble with fundamental parts of their futures is a warning that holds as much for those able to bargain on an equal footing with the other party as it is for those facing weak bargaining positions. The protection of the most vulnerable calls for yet further tools, highlighting areas in which the need for extra protection via extra bargaining strength is acute. In so doing, a polity may still fundamentally build on the heritage of the social contract, which is meant to be at the disposal of all.

32 See generally Karl Marx, On the Jewish Question, in WrITINGS OF THE Young MARX ON PhILOSOPHY AND SocieTY 216 (Loyd D. Easton \& Kurt H. Guddat, eds. trans., 1967) (arguing that religion will play a prominent role in the secular state and that economic inequality will always bind individuals to material constraints on freedom); C.B. MacPherson, The Political Theory of Possessive Individualism: HobBes to Locke (1962) (arguing that the "possessive quality" of individualism in classical liberalism constructs society as little more than a system of economic relations rooted in property). 
When the state endorses a fresh species of consent, it is shifting the ground of its own rationale and legitimacy. It is the state that finally shapes and authorizes the types of agreement that will bind in the private as well as public sectors. Its move from a restricted to an extended conception of legitimate risk to which one consents is ultimately its initiative and responsibility. The move certainly has its reasons, often expressed in terms of economic efficiency and institutional efficacy, allowing the polity to hold its own among international competitors. But the social and individual cost is high. We should not hide this cost beneath the cloak of saying to someone whose basic rights are weakened and who is thereby made a great deal worse off, "but you did agree after all." 